\title{
Efficiency of chitosan synergism with clove essential oil in the coating of intentionally contaminated Tambaqui fillets
}

\section{Eficiência do sinergismo de quitosana com óleo essencial de cravo no revestimento de filés de tambaqui contaminados intencionalmente}

\author{
Brenda Borges Vieira ${ }^{1}$; Elaine Araújo de Carvalho; ${ }^{1}$ Aline Simões da Rocha Bispo²; \\ Mariza Alves Ferreira ${ }^{3}$; Norma Suely Evangelista-Barreto ${ }^{4 *}$
}

\section{Highlights:}

Gram-positive bacteria are more sensitive to chitosan and clove essential oil than Gram-negative bacteria.

The edible coating of chitosan with clove essential oil significantly reduced the number of $L$. monocytogenes and $S$. aureus in the Tambaqui fillets.

Clove essential oil potentiated the antimicrobial effect of chitosan on Tambaqui fillets.

\begin{abstract}
The edible coating of chitosan with clove essential oil (CEO) was studied for its ability to reduce the microbial growth of pathogens (Escherichia coli O157:H7 CDCEDL933, Listeria monocytogenes CERELA, Salmonella Enteritidis ATCC13076, Staphylococcus aureus ATCC43300, and Pseudomonas aeruginosa ATCC27853) in Tambaqui fillets kept under refrigeration. In in vitro tests, chitosan showed higher antimicrobial activity against $S$. aureus and L. monocytogenes (MIC $0.5 \%$ ), and CEO for $L$. monocytogenes (MIC 0.08\%). Based on the antimicrobial activity of chitosan and CEO, Tambaqui fillets were subjected to different treatments, T1: chitosan $2 \%$; T2: chitosan $2 \%+\mathrm{CEO} 0.16 \%$, and T3: chitosan $0.5 \%+$ CEO $0.08 \%$, kept at $4{ }^{\circ} \mathrm{C}$ for $72 \mathrm{~h}$. The chitosan coating, incorporated with CEO, inhibited microorganisms in Tambaqui fillets and enhanced coating efficiency $(\mathrm{p}<0.05)$. It was most effective against $L$. monocytogenes and $S$. aureus at the lowest CEO concentration (0.08\%). Chitosan coating in combination with CEO enhanced the antimicrobial effect of pathogens on Tambaqui fillets, increased their shelf life under refrigeration, and was more effective against Gram-positive pathogens than Gram-negative pathogens.
\end{abstract}

Key words: Edible coating. Listeria monocytogenes. Natural antimicrobials. Pathogens.

\section{Resumo}

O revestimento comestível de quitosana com óleo essencial de cravo (OEC) foi estudado por sua capacidade em reduzir o crescimento microbiano de patógenos (Escherichia coli O157:H7 CDCEDL933, Listeria monocytogenes CERELA Salmonella Enteritidis ATCC 13076, Staphylococcus

\footnotetext{
1 Mestres em Microbiologia Agrícola, Centro de Ciências Agrárias, Biológicas e Ambientais, CCAAB, Universidade Federal do Recôncavo da Bahia, UFRB, Cruz das Almas, BA, Brasil. E-mail: brendaborgesv@hotmail.com; elai_carvalho@hotmail.com

2 Pesquisadora de Pós-Doutorado do Programa de Pós-Graduação em Microbiologia Agrícola, CCAAB, UFRB, Cruz das Almas, BA, Brasil. E-mail: alinesimoesbispo@gmail.com

3 Pesquisadora de Pós-Doutorado do Programa de Pós-Graduação em Ciência Animal, CCAAB, UFRB, Cruz das Almas, BA, Brasil. E-mail: marizaufrb@yahoo.com.br

4 Prof ${ }^{\mathrm{a}} \mathrm{Dr}^{\mathrm{a}}$, CCAAB, UFRB, Cruz das Almas, BA, Brasil. E-mail: nsevangelista@ufrb.edu.br

* Author for correspondence
} 
aureus ATCC43300 e Pseudomonas aeruginosa ATCC27853) em filés de tambaqui mantidos sob refrigeração. Nos testes in vitro, a quitosana apresentou maior atividade antimicrobiana para $S$. aureus e L. monocytogenes (CIM 0,5\%) e o OEC para L. monocytogenes (CIM 0,08\%). Com base na atividade antimicrobiana da quitosana e OEC, os filés de Tambaqui foram submetidos a T1: quitosana a $2 \%$; T2: quitosana $2 \%+$ OEC $0,16 \%$ e T3: quitosana $0,5 \%+$ OEC $0,08 \%$, mantidos a $4{ }^{\circ} \mathrm{C}$ por $72 \mathrm{~h}$. O revestimento de quitosana, incorporado ao $\mathrm{OEC}$, inibiu os micro-organismos nos filés de Tambaqui aumentando a eficiência do revestimento $(\mathrm{p}<0,05)$; e foi mais eficaz para L. monocytogenes e $S$. aureus na menor concentração do $\operatorname{OEC}(0,08 \%)$. O revestimento de quitosana quando combinado ao OEC aumentou o efeito antimicrobiano de patógenos nos filés de Tambaqui, aumentando sua vida útil sob refrigeração, sendo mais eficaz contra patógenos Gram positivos do que os patógenos Gram negativos. Palavras-chave: Antimicrobianos naturais. Listeria monocytogenes. Patógenos. Revestimento comestível.

\section{Introduction}

Worldwide aquaculture production continues to grow faster than any other food sector (Food and Agriculture Organization [FAO], 2018). In Brazil, Tambaqui (Colossoma macropomum) is the most predominant native fish species produced via aquaculture and is second overall, with the nonnative Nile tilapia being the most produced species. Tambaqui, which originates from the Amazon River basin, makes up $27.7 \%$ of the total fish production in Brazil (Seafood Brazil, 2018).

The search for healthier and less processed foods has contributed to the increased commercialization of fish fillets, due to their nutritional value and ease of which it can be preparation (Yu, Li, Xu, Jiang, \& Xia, 2017). When compared to other types of animal meat, fish have a shorter shelf life due to postmortem changes caused by endogenous biochemical reactions (Yu et al., 2018) and, their chemical composition, which favors the rapid growth of pathogenic microorganisms, leading to spoilage (Chaparro-Hernández et al., 2015).

One way to protect fish and fish fillets while minimizing microbial spoilage is the application of edible coatings (EC), that act as a barrier against moisture, oxygen, and light, thereby preventing dehydration, lipid oxidation, and color degradation (Martínez, Salmerón, Epelde, Vicente, \& Vega, 2018). Polysaccharide coatings are the most commonly used type of EC. Chitosan, a polymer derived from chiton, is an ideal biopolymer for food application. It is a natural, biodegradable, biocompatible, and displays antimicrobial and antioxidant properties. Chitosan also has the ability to form edible films and coatings, and has been classified as a Generally Recognized as Safe (GRAS) product since 2001 (United State Food and Drug Administration [USFDA], 2013). When combined with lipids such as essential oils, chitosan EC can display optimized characteristics (Dehghani, Hosseini, \& Regenstein, 2018).

Essential oils are rich in bioactive compounds, making these lipids suitable for incorporation into $\mathrm{EC}$, as they enhance the preservative effect of the coating by attributing sensory characteristics to the food (Sivakumar \& Bautista-Nanos, 2014). The multifunctional bioactivity of clove essential oil can be attributed to its main compound, eugenol (Heredia-Guerrero et al., 2018).

Although several studies have reported the efficacy of chitosan in preserving the quality of freshwater fish such as grass carp (Yu et al., 2018), Nile tilapia (Alsaggaf, Moussa, \& Tayel, 2017) and rainbow trout (Ozogul et al., 2017), there are no reports of chitosan associated with clove essential oil - CEO used in the microbiological preservation of Tambaqui fillets kept under refrigeration. The objective of this study was to evaluate the efficacy of chitosan association with clove essential oil in the edible coating of intentionally contaminated Tambaqui fillets. 


\section{Material and Methods}

Microorganisms

The microorganisms used were Escherichia coli O157:H7 CDCEDL933, Listeria monocytogenes CERELA, Salmonella Enteretidis ATCC13076, Staphylococcus aureus ATCC43300 and Pseudomonas aeruginosa ATCC27853. The strains were activated on tryptone soy agar (Himedia $^{\circledR}$, Mumbai, India) and incubated at $37^{\circ} \mathrm{C}$ for $24 \mathrm{~h}$.

\section{Chitosan antimicrobial activity}

High molecular weight chitosan $(310 \mathrm{kDa})$ with a 91.5\% deacetylation degree, obtained from Polymar Indústria e Comércio LTDA (Fortaleza, Ceará, Brazil), was used. The stock solution was prepared by dissolving chitosan $2 \%(\mathrm{w} / \mathrm{v})$ in $1 \%(\mathrm{v} / \mathrm{v})$ lactic acid solution with agitation using a magnetic stirrer for $24 \mathrm{~h}$. Aliquots of $50 \mu \mathrm{L}$ of the bacterial

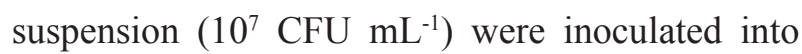
nutrient agar plates $\left(\right.$ Himedia $^{\circledR}$ ) along with 100 $\mu \mathrm{L}$ of chitosan solution at different concentrations $(0.0625 \%, 0.125 \%, 0.25 \%, 0.5 \%, 1 \%$, and $2 \%)$ and incubated at $37{ }^{\circ} \mathrm{C}$ for $24 \mathrm{~h}$, in triplicate. As control, nutrient agar plates inoculated with sterile water and $1 \%$ lactic acid solution were used.

Chitosan inhibition rate (IR) was calculated using the equation:

$$
\operatorname{IR}(\%)=\frac{\mathrm{N} 1-\mathrm{N} 2}{\mathrm{~N} 1} \times 100
$$

Where IR is the percentage inhibition rate; $\mathrm{N} 1$ is the number of colonies on sterile water plates and $\mathrm{N} 2$ is the number of colonies after treatment at different concentrations of chitosan (Wang \& Wang, 2011).

The minimum inhibitory concentration (MIC) was defined as the lowest concentration capable of reducing $99 \%$ of viable bacteria and the minimum bactericidal concentration (MBC) was defined as the lowest concentration capable of eliminating $99.9 \%$ of viable bacteria (Kuete et al., 2008).
Antimicrobial activity of clove essential oil

Clove essential oil (Syzygium aromaticum, CEO) was obtained commercially in $10 \mathrm{~mL}$ volumes from Terra Flor Aromatherapy ${ }^{\odot}$ (Alto Paraíso, Goiás, Brazil). The antimicrobial activity of the CEO was tested via plate diffusion disc technique according to the M2-A8 protocol of the National Committee for Clinical Laboratory Standards [NCCLS] (2003), adapted for natural products. The bacterial suspension $\left(10^{7} \mathrm{CFU} \mathrm{mL}^{-1}\right)$ was seeded on MuellerHinton agar plates $\left(\right.$ Himedia $^{\circledR}$ ) and filter paper discs of $6 \mathrm{~mm}$ in diameter were imbibed with $10 \mu \mathrm{L}$ CEO. The reading was obtained after $18-24 \mathrm{~h}$ of incubation at $37^{\circ} \mathrm{C}$ by growth inhibition halos using a digital caliper.

To determine the MIC, $1 \mathrm{~g}$ of CEO was diluted using methanol to a concentration of $640 \mathrm{mg}$ $\mathrm{mL}^{-1}$ (Solution I). A second 1:100 dilution was performed using Mueller-Hinton broth (Himedia ${ }^{\circledR}$ ) at a concentration of $6.4 \mathrm{mg} \mathrm{mL}^{-1}$. The MIC was determined based on Clinical and Laboratoy Standards Institute document M07-A10 (CLSI, 2018 ) with final concentrations at $0.32 \%, 0.16 \%$, $0.08 \%, \quad 0.04 \%, \quad 0.02 \%, \quad 0.01 \%, \quad 0.005 \%$, and $0.0025 \%$, in triplicate. Readings were obtained with $0.01 \%(\mathrm{w} / \mathrm{v})$ sodium resazurin dye (SigmaAldrich, Sant Louis, EUA). The MIC and MBC are previously defined in section 2.2.

\section{Edible coating of Tambaqui fillets}

The $500 \mathrm{~mL}$ coating solution was composed of chitosan (10 g; final concentration of $2 \%$ ) and $85 \%$ lactic acid $(5.88 \mathrm{~mL}$; final concentration of $1 \%$ $\mathrm{w} / \mathrm{v})$. Chitosan powder was dissolved by stirring continuously for $2 \mathrm{~h}$ (Cahú et al., 2012) then the $\mathrm{pH}$ was adjusted to 6.0. CEO $(0.4 \mathrm{~g}$ and $0.8 \mathrm{~g})$ was then subsequently added to achieve a final concentration of $0.08 \%$ and $0.16 \%$, respectively.

Fresh Tambaquis weighing approximately $6 \mathrm{~kg}$ were commercially purchased, filleted into $100 \mathrm{~g}$ portions, and separated into groups according to 
the test microorganism (E. coli, L. monocytogenes, $S$. Enteritidis, S. aureus and P. aeruginosa). The antimicrobial activity of the chitosan + EOC coating was evaluated according to Barbosa et al. (2009), with adaptations. Initially, microbiological analysis was performed on the fillets to verify the presence of the test-pathogens. For intentional contamination, the fillets were inoculated with a bacterial suspension of $10^{6} \mathrm{CFU} \mathrm{mL} \mathrm{m}^{-1}$ for each indicator pathogen. After 30 minutes of contact, the fillets ( 9 per treatment) were immersed in $500 \mathrm{~mL}$ in the following coating treatments for 10 seconds: T1 (chitosan 2\%), T2 (chitosan 2\% + CEO 0.16\%), T3 (chitosan $0.5 \%+$ CEO 0.08\%), and control (sterile water). The samples were then dried for 1 minute at $25^{\circ} \mathrm{C}$. Each fillet was subsequently packaged using a plastic polyethylene film and were stored at $4{ }^{\circ} \mathrm{C}$ $\pm 1{ }^{\circ} \mathrm{C}$ for $72 \mathrm{~h}$. Analyses for each pathogen were performed at 24, 48 and $72 \mathrm{~h}$ intervals (Silva et al., 2010). All assays were performed in triplicate.

\section{Statistical analysis}

The dates were subjected to analysis of variance (ANOVA) and means evaluated by Tukey test at $5 \%$ significance $(p<0.05)$. The analyses were performed using the statistical program $\mathrm{R}$ Core Team (R Core Team [R], 2017).

\section{Results and Discussion}

\section{Chitosan antimicrobial activity}

Chitosan was more effective against Grampositive bacteria than Gram-negative bacteria, especially $S$. aureus, whose growth was inhibited with $0.5 \%$ chitosan (Table 1 ). The MIC and MBC of chitosan were only found for $L$. monocytogenes and $S$. aureus (Table 1). It was not possible to determine the antimicrobial activity of chitosan at concentrations greater than $2 \%$ as it became more viscous at high concentrations, making it difficult to carry out the test. The antimicrobial activity of chitosan against L. monocytogenes and $S$. aureus was attributed to a greater amount of positive charges present in the chitosan molecule as its concentration increases. The protonated amino groups $\left(\mathrm{NH}^{+}\right)$within chitosan selectively bind to the cell membrane of negatively charged microorganisms and alter their cell activity and membrane permeability (Cai et al., 2015). This behavior was also observed by Wang and Wang (2011): by analyzing the antimicrobial activity of chitosan and its derivatives, they observed the inhibition of $S$. aureus due to an increased concentration of chitosan.

For Gram-negative bacteria, the chitosan inhibition rate varied, revealing that it was not influenced by an increase in concentration. The highest inhibition rate $(93.87 \%)$ was obtained for $P$. aeruginosa, while $E$. coli showed greater resistance to chitosan with an inhibition rate below $58.98 \%$ and high lactic acid interference (Table 1). The antimicrobial action of chitosan is influenced by several factors, such as environmental conditions, chemical substrates present in the environment, structural conditions such as the degree of deacetylation, molecular weight, and forms derived from chitosan and its concentration, among others (Hosseinnejad \& Jafari, 2016). 
Table 1

Chitosan inhibition rate (\%) against food-borne pathogenic microorganisms

\begin{tabular}{lccccccccc}
\hline \multirow{2}{*}{ Microorganisms } & \multicolumn{8}{c}{ Chitosan Concentration (w/v) / Inhibition Rate (\%) } \\
\cline { 2 - 10 } & LA 1\% & 2 & 1 & 0.5 & 0.25 & 0.125 & 0.0625 & MIC & CBM \\
\hline E. coli O157:H7 & 52.40 & 16.09 & 08.32 & 19.36 & 54.70 & 33.19 & 58.98 & - & - \\
L. monocytogenes & 05.20 & 100.0 & 97.20 & 96.80 & 81.30 & 72.00 & 58.20 & 2.00 & 2.00 \\
P. aeruginosa & 60.40 & 93.87 & 88.68 & 86.65 & 78.09 & 71.08 & 81.85 & - & - \\
S. Enteretidis & 40.64 & 76.42 & 62.65 & 61.05 & 54.98 & 66.80 & 69.00 & - & - \\
S. aureus & 12.56 & 100.0 & 100.0 & 100.0 & 99.62 & 98.84 & 93.27 & 0.25 & 0.50 \\
\hline
\end{tabular}

LA: lactic acid; MIC: Minimum Inhibitory Concentration; MBC: Minimum Bactericidal Concentration - not inhibition.

Among Gram-negative microorganisms, E. coli O157:H7 has been considered one of the most acidresistant serovars (Mittelstaedt \& Carvalho, 2006). A $1 \%$ solution of lactic acid showed significant inhibition of the pathogen E. coli $\mathrm{O} 157: \mathrm{H} 7$ (Table 1). The undissociated form of lactic acid (weak organic acid), when accumulated in the cell membrane, is thought to promoted membrane disruption by inhibiting essential metabolic reactions (Jay, 2005). The resistance presented by E. coli $\mathrm{O} 157: \mathrm{H} 7$ to chitosan has been related to several adaptive genetic mechanisms of virulence, and is necessary for its survival (Khachatryan, Hancock, Besser, \& Call, 2005).

\section{Antimicrobial activity of clove essential oil}

The antimicrobial activity of CEO in the disc diffusion test showed weak inhibition of $P$. aeruginosa $[<13.9 \mathrm{~mm}$ (Silveira et al., 2012)], moderate inhibition of $S$. Enteretidis, E. coli, and $S$. aureus $(14-18 \mathrm{~mm})$, and strong inhibition $(\mathrm{p}<0.05)$ of L. monocytogenes (> $18 \mathrm{~mm}$ ) (Table 2 ).

Table 2

Antimicrobial activity of clove essential oil by disc diffusion and broth dilution against pathogenic microorganisms of food interest

\begin{tabular}{|c|c|c|c|c|c|c|}
\hline \multirow{3}{*}{ Microorganisms } & \multicolumn{6}{|c|}{ Antimicrobial activity } \\
\hline & \multicolumn{2}{|c|}{ Disc diffusion $(\mathrm{mm})$} & \multicolumn{4}{|c|}{ Broth dilution $\left(\mu \mathrm{g} \mathrm{mL} L^{-1}\right)$} \\
\hline & Inhibition halos & CLO & $\mathrm{MIC}$ & $\mathrm{MBC}$ & CLO & Methanol \\
\hline E. coli $\mathrm{O} 157: \mathrm{H} 7$ & $15.08 \pm 0.41 \mathrm{c}$ & 30.38 & 1600 & - & 60 & NI \\
\hline L. monocytogenes & $19.36 \pm 0.63 a$ & 26.03 & 800 & - & 30 & NI \\
\hline P. aeruginosa & $09.75 \pm 0.52 d$ & 21.09 & 3200 & - & 120 & NI \\
\hline$S$. Enteretidis & $15.51 \pm 1.57 \mathrm{c}$ & 28.53 & 1600 & - & 30 & NI \\
\hline S. aureus & $17.19 \pm 0.42 b$ & 31.51 & 1600 & - & 60 & NI \\
\hline
\end{tabular}

Area of inhibition expressed as the average of three repetitions \pm standard deviation. Degree of inhibition: $<13.9$ mm: weak; 14 - $18 \mathrm{~mm}$ : moderate; >18 mm: strong (Silveira et al., 2012). NI: no inhibition, CLO: chloramphenicol. MIC: Minimum Inhibitory Concentration. MBC: Minimum Bactericidal Concentration. High activity: 50 - $500 \mu \mathrm{g} \mathrm{mL}^{-1}$; moderate activity: $500-1500 \mu \mathrm{g} \mathrm{L}^{-}$ '; weak activity: $>1500 \mu \mathrm{g} \mathrm{mL} \mathrm{m}^{-1}$ (Sartoratto et al., 2004). Averages followed by the same letter in the column are not significantly different $(\mathrm{p}<0.05)$. 
The results of the diffusion disc test differed from the data obtained from the broth dilution test (MIC), with CEO showing weak antimicrobial activity against $P$. aeruginosa, $S$. Enteretidis, $E$. coli, and S. aureus [>1500 $\boldsymbol{\mu g} \mathrm{mL}^{-1}$ (Sartoratto et al., 2004)], and moderate antimicrobial activity for $L$. monocytogenes $\left(500\right.$ - $1500 \mu \mathrm{g} \mathrm{mL}^{-1}$ ) (Table 2). The concentrations obtained in the MIC experiments were found be bacteriostatic.

The greater sensitivity of Gram-positive bacteria (L. monocytogenes and S. aureus) to CEO is related to the simple structure of their cell wall, compared to the complexity of that of Gram-negative bacteria that are polysaccharide-rich, inhibiting the penetration of antimicrobial substances (Burt, 2004). The bactericidal activity of CEO has been attributed to its majority constituent, eugenol (low molecular weight), and the lipophilic components of essential oils that promote high cell membranes penetration with extravasation of other cellular components, including intracellular proteins, and cell death (Devi, Nisha, Sakthivel, \& Pandian, 2010).

When comparing the two methods used (disk diffusion and MIC), results indicate that the diffusion method can be used as a preliminary method because it determines the sensitivity of many microorganisms to certain substances, is easy to perform, and requires small amounts of sample, presenting semiquantitative results (Kalemba \& Kunicka, 2003).

\section{Antimicrobial potential of chitosan coating associated with clove essential oil in intentionally contaminated Tambaqui fillets}

To ensure that initial number of bacteria in the fish fillets was the same as that in the inoculum used in the initial contamination, microbial analysis of the fillets in fresh fish was performed before treatments, which showed that the fillets had zero counts for the test bacteria (Table 3). All treatments were effective in reducing $S$. aureus in Tambaqui fillets in the first $24 \mathrm{~h}$ of storage, with a reduction of $2.9 \log \mathrm{CFU} \mathrm{g}^{-1}$ cycles in T2 (Table 3) when compared to the control. Total inhibition of $S$. aureus was obtained at $24 \mathrm{~h}$ in $\mathrm{T} 3$, and at $48 \mathrm{~h}$ in $\mathrm{T} 1$ and $\mathrm{T} 2$. The control reduced $\sim 2 \log \mathrm{CFU} \mathrm{g}^{-1}$ cycles (due to immersion in water), maintaining the same growth (bacteriostatic effect) until the end of storage $(p<0.05)$. The T3 treatment showed a higher efficacy in pathogen reduction after $24 \mathrm{~h}(\mathrm{p}<0.05)$, demonstrating that the synergism of chitosan and CEO at lower concentrations is more effective.

Fillets contaminated with $L$. monocytogenes also showed growth reduction $(\mathrm{p}<0.05)$ in the $\mathrm{T} 3$ treatment after $48 \mathrm{~h}$ (Table 3 ). The chitosan + CEO effect (T2 and T3) had the best antilisterial effect, with a reduction of $\sim 3 \log \mathrm{CFU} \mathrm{g}^{-1}$ cycles after 24 $\mathrm{h}$ in $\mathrm{T} 2$ treatment, and $2.3 \log \mathrm{CFU} \mathrm{g}{ }^{-1}$ cycles in T3 (Table 3). The microbial reduction in the control sample was not significant ( $\mathrm{p}>0.05$ ) (Table 3 ).

Similar to the results observed in in vitro tests, the treatments were more effective in reducing Gram-positive bacteria compared to Gram-negative bacteria. The coating was more effective for $P$. aeruginosa, particularly at the lowest concentration (T3), which showed a reduction of $3.46 \log \mathrm{CFU} \mathrm{g}^{-1}$ cycles after $72 \mathrm{~h}$ compared to the control (Table 3 ).

The edible coating was more efficient against $S$. Enteritidis (reduction of $2.27 \log$ cycles of CFU g ${ }^{-1}$ ) after $48 \mathrm{~h}$ in treatment T2. In E. coli O157:H7, the $\mathrm{T} 3$ treatment showed less reduction in the first $24 \mathrm{~h}$ compared to $\mathrm{T} 2$ treatment, and at $72 \mathrm{~h}$, the microbial reduction values in both treatments (T2 and T3) did not differ significantly (Table 3 ). 
Table 3

Effect of chitosan coating and its association with clove essential oil on Tambaqui fillets intentionally contaminated with pathogenic microorganisms, kept under refrigeration $\left(4^{\circ} \mathrm{C}\right)$

\begin{tabular}{|c|c|c|c|c|c|c|}
\hline \multirow{2}{*}{ Microorganisms } & \multirow[t]{2}{*}{ Initial Cont. } & \multirow{2}{*}{$\begin{array}{l}\text { Time } \\
\text { (h) }\end{array}$} & Control & $\mathrm{T} 1$ & $\mathrm{~T} 2$ & T3 \\
\hline & & & \multicolumn{4}{|c|}{$\log \mathrm{CFU} \mathrm{g}^{-1}$} \\
\hline \multirow{4}{*}{ S. aureus } & \multirow{4}{*}{0.0} & 0 & $6.00 \mathrm{Aa}$ & $6.00 \mathrm{Aa}$ & $6.00 \mathrm{Aa}$ & $6.00 \mathrm{Aa}$ \\
\hline & & 24 & $4.16 \mathrm{Ab}$ & $4.28 \mathrm{Ab}$ & $3.10 \mathrm{Bb}$ & $0.00 \mathrm{Cb}$ \\
\hline & & 48 & $4.27 \mathrm{Ab}$ & $0.00 \mathrm{Bc}$ & $0.00 \mathrm{Bc}$ & $0.00 \mathrm{Bb}$ \\
\hline & & 72 & $4.13 \mathrm{Ab}$ & $0.00 \mathrm{Bc}$ & $0.00 \mathrm{Bc}$ & $0.00 \mathrm{Bb}$ \\
\hline \multirow{4}{*}{ L. monocytogenes } & \multirow{4}{*}{0.0} & 0 & $6.00 \mathrm{Aa}$ & $6.00 \mathrm{Aa}$ & $6.00 \mathrm{Aa}$ & $6.00 \mathrm{Aa}$ \\
\hline & & 24 & 5.58Aab & $3.31 \mathrm{BCb}$ & $3.00 \mathrm{Cb}$ & $3.70 \mathrm{Bb}$ \\
\hline & & 48 & $5.29 \mathrm{Abc}$ & $3.53 \mathrm{Bb}$ & $2.19 \mathrm{Cc}$ & $0.00 \mathrm{Dc}$ \\
\hline & & 72 & $4.85 \mathrm{Ac}$ & $3.19 \mathrm{Bb}$ & $0.00 \mathrm{Cd}$ & $0.00 \mathrm{Cc}$ \\
\hline \multirow{4}{*}{$S$. Enteretidis } & \multirow{4}{*}{0.0} & 0 & $6.00 \mathrm{Aa}$ & $6.00 \mathrm{Aa}$ & $6.00 \mathrm{Aa}$ & $6.00 \mathrm{Aa}$ \\
\hline & & 24 & $5.10 \mathrm{Ab}$ & $4.69 \mathrm{Bb}$ & $4.22 \mathrm{Cb}$ & $4.74 \mathrm{Bb}$ \\
\hline & & 48 & $5.18 \mathrm{Ab}$ & $4.55 \mathrm{Bb}$ & $3.73 \mathrm{Cb}$ & $4.52 \mathrm{Bb}$ \\
\hline & & 72 & $4.79 \mathrm{Ac}$ & $4.08 \mathrm{Bc}$ & $3.66 \mathrm{Cb}$ & 4.22Bc \\
\hline \multirow{4}{*}{ E. coli $\mathrm{O} 157: \mathrm{H} 7$} & \multirow{4}{*}{0.0} & 0 & $6.00 \mathrm{Aa}$ & $6.00 \mathrm{Aa}$ & $6.00 \mathrm{Aa}$ & $6.00 \mathrm{Aa}$ \\
\hline & & 24 & 6.06Aa & $5.25 \mathrm{Bb}$ & $5.27 \mathrm{Bb}$ & $4.93 \mathrm{Bb}$ \\
\hline & & 48 & $6.11 \mathrm{Aa}$ & $5.05 \mathrm{Bb}$ & 5.68Aab & $4.81 \mathrm{Bb}$ \\
\hline & & 72 & $5.72 \mathrm{Aa}$ & $4.20 \mathrm{Bc}$ & $4.56 \mathrm{Bc}$ & $4.65 \mathrm{Bb}$ \\
\hline \multirow{4}{*}{ P. aeruginosa } & \multirow{4}{*}{0.0} & 0 & $6.00 \mathrm{Aa}$ & $6.00 \mathrm{Aa}$ & $6.00 \mathrm{Aa}$ & $6.00 \mathrm{Aa}$ \\
\hline & & 24 & $5.62 \mathrm{Ab}$ & $3.98 \mathrm{Cb}$ & $4.31 \mathrm{Bb}$ & $3.00 \mathrm{Db}$ \\
\hline & & 48 & $5.41 \mathrm{Ab}$ & $3.88 \mathrm{Bb}$ & $3.47 \mathrm{Cc}$ & $2.98 \mathrm{Db}$ \\
\hline & & 72 & $5.08 \mathrm{Ac}$ & $3.24 \mathrm{Bc}$ & 2.93Bd & $2.54 \mathrm{Cc}$ \\
\hline
\end{tabular}

Initial Cont: Initial contamination of fish. Control: uncoated sample; T1: chitosan 2\%; T2: chitosan 2\% + CEO 0.16\%; T3: chitosan $0.5 \%+$ CEO $0.08 \%$. Means followed by equal letters do not differ from each other by the Tukey test $(\mathrm{p}<0.05)$, and uppercase letters between rows and lowercase letters between columns are compared.

The difference in inhibition of Gram-positive (L. monocytogenes and S. aureus) and Gramnegative (E. coli, P. aeruginosa and $S$. Enteretidis) bacteria by the chitosan + CEO association (Table 1) can be attributed to chitosan's molecular weight (>310 kDa). High molecular weight of chitosan forms a film around Gram-positive bacterial cells, preventing nutrient absorption (Devlieghere, Vermeiren, \& Debevere, 2004).

Another factor that interferes with coating efficiency is the bacterial cell envelopes. The cellular envelope of L. monocytogenes and S. aureus, composed mainly of peptide glycans, allows easier entry of molecules into the cell. The cell membrane of E. coli, $P$. aeruginosa, and $S$. Enteretidis are composed of lipopolysaccharides, phospholipids, and lipoproteins that act as a barrier against the penetration of high molecular weight molecules such as chitosan (Mohamed \& Al-Mehbad, 2013).

Upadhyay et al. (2015) analyzed the effect of chitosan associated with phytochemicals and their results indicated that the incorporation of $0.4 \%$ eugenol significantly increased the antimicrobial coating efficacy, reducing $L$. monocytogenes counts by at least $4-5 \log \mathrm{CFU} \mathrm{g}{ }^{-1}$ at the end of 42 days of storage at $4{ }^{\circ} \mathrm{C}$ when compared to that of the control. 
The antimicrobial efficacy of chitosan coating on Tambaqui fillets can be further attributed to the oxygen barrier that reduces the number of bacteria, specifically aerobic bacteria such as $P$. aeruginosa (Jeon, Kamil, \& Shahidi, 2002).

Although the antimicrobial and antioxidant activities of essential oils have been demonstrated previously (Yu et al., 2018), one of the major limitations of their use is the negative effect they have on the taste of food; this may affect consumer preference for the fish fillets. Vieira et al. (2019) performed sensory analysis of chitosan + CEO in Tambaqui fillets and reported that after treating the Tambaqui fillets with chitosan $(2 \%)$ and chitosan + CEO $(0.16 \%$ and $0.08 \%$, respectively), several parameters such as color, texture, and aroma were well accepted by the tasters, and a score $>5$ was assigned for these parameters (I liked it, I liked it a lot); however, the tasters assigned a score of 4 (neither like or dislike) for flavor in samples containing CEO. According to the authors, this response may be due the fact that clove is not a common ingredient in Bahian cuisine.

\section{Conclusion}

The synergism of chitosan coating with CEO is most effective in inhibiting Gram-positive microorganisms. Results indicate that CEOassociated chitosan coating is a potential alternative to improve the safety of chilled fishery products as it reduces spoilage-related microorganisms such as $P$. aeruginosa, as well as other important pathogens associated with food such as $S$. aureus and $L$. monocytogenes.

\section{Acknowledgments}

This study was funded by Coordenação de Aperfeiçoamento de Pessoal de Nível Superior Brazil (CAPES) - Finance Code 001.

\section{References}

Alsaggaf, M. S., Moussa, S. H., \& Tayel, A. A. (2017). Application of fungal chitosan incorporated with pomegranate peel extract as edible coating for microbiological, chemical and sensorial quality enhancement of Nile tilapia fillets. International Journal of Biological Macromolecules, 99(1), 499505. doi: 10.1016/j.ijbiomac.2017.03.017

Barbosa, L. N., Rall, V. L. M., Fernandes, A. A. H., Ushimaru, P. I., Probst, I. S., \& Fernandes, A. (2009). Essential oils against foodborne pathogens and spoilage bacteria in minced meat. Foodborne Pathogenes and Diseases, 6(6), 725-728. doi: 10.1089/fpd.2009.0282

Burt, S. (2004). Essential oils: their antibacterial properties and potential applications in foods - a review. International Journal of Food Microbiology, 94(3), 223-256. doi: 10.1016/j.ijfoodmicro.2004.03.022

Cahú, T. B., Santos, S. D., Mendes, A., Córdula, C. R., Chavante, S. F., Carvalho, L. B., \& Bezerra, R. S. (2012). Recovery of protein, chitin, carotenoids and glycosaminoglycans from Pacific white shrimp (Litopenaeus vannamei) processing waste. Process Biochemistry, 47(4), 570-577. doi: 10.1016/j. procbio.2011.12.012

Cai, J., Dang, Q., Liu, C., Wang, T., Fan, B., Yan, J., \& Xu, Y. (2015). Preparation, characterization and antibacterial activity of O-acetyl-chitosan-N2-hydroxypropyl trimethyl ammonium chloride. International Journal of Biological Macromolecules, 80(1), 8-15. doi: 10.1016/j.ijbiomac.2015.05.061

Chaparro-Hernández, S., Ruíz-Cruz, S., Márquez-Ríos, E., Ocaño-Higuera, V. M., Valenzuela-López, C. C., Ornelas-Paz, J. J., \& Del-Toro-Sánchez, C. L. (2015). Effect of chitosan-carvacrol edible coatings on the quality and shelf life of tilapia (Oreochromis niloticus) fillets stored in ice. Food Science and Technology, 35(4), 734-741. doi: 10.1590/1678457X.6841

Clinical and Laboratory Standards Institute (2018). Methods for dilution antimicrobial susceptibility tests for bacteria that grow aerobically. (11 th ed.). CLSI M07-A10. Wayne, PA: Clinical and Laboratory Standards Institute. Retrieved from www.clsi.org

Dehghani, S., Hosseini, S. V., \& Regenstein, J. M. (2018). Edible films and coatings in seafood preservation: a review. Food Chemistry, 240(1), 505-513. doi: 10.1016/j.foodchem.2017.07.034 
Devi, K. P., Nisha, S. A., Sakthivel, R., \& Pandian, S. K. (2010). Eugenol (an essential oil of clove) acts as an antibacterial agent against Salmonella typhi by disrupting the cellular membrane. Journal of Ethnopharmacology, 130(1), 107-115. doi: 10.1016/j.jep.2010.04.025

Devlieghere, F., Vermeiren, L., \& Debevere, J. (2004). New preservation technologies: possibilities and limitations. International Dairy Journal, 14(4), 273285. doi: 10.1016/j.idairyj.2003.07.002

Food and Agriculture Organization (2018). The state of world fisheries and aquaculture 2018 - Meeting the sustainable development goals. Rome: Food and Agriculture Organization of the United Nations. Retrieved from www.fao.org/publications

Heredia-Guerrero, J. A., Ceseracciu, L., Guzman-Puyol, S., Paul, U. C., Alfaro-Pulido, A., Grande, C., \& Bayer, I. S. (2018). Antimicrobial, antioxidant, and waterproof RTV silicone-ethyl cellulose composites containing clove essential oil. Carbohydrate Polymers, 192(1), 150-158. doi: 10.1016/j. carbpol.2018. 03.050

Hosseinnejad, M., \& Jafari, S. M. (2016). Evaluation of different factors affecting antimicrobial properties of chitosan. International Journal of Biological Macromolecules, 85(1), 467-475. doi: 10.1016/j. ijbiomac. 2016.01.022

Jay, J. M. (2005). Microbiologia de alimentos (6a ed.). Porto Alegre: Artmed.

Jeon, Y. J., Kamil, J. Y. V. A., \& Shahidi, F. (2002). Chitosan as an edible invisible film for quality preservation of herring and Atlantic cod. Journal of Agricultural and Food Chemistry, 50(18), 51675178. doi: 10.1021/jf0116931

Kalemba, D., \& Kunicka, A. (2003). Antibacterial and antifungal properties of essential oils. Current Medical Chemistry, 10(10), 813-829. doi: 10.2174/0929867033457719

Khachatryan, A. R., Hancock, D. D., Besser, T. E., \& Call, D. R. (2005). Antimicrobial drug resistance genes do not convey a secondary fitness advantage to calf-adapted Escherichia coli. Applied and Environmental Microbiology, 72(1), 443-448. doi: 10.1128/AEM.72.1.443-448.2006

Kuete, V., Ngameni, B., Simo, C. C. S., Tankeu, R. K., Ngadjui, T., Meyer, J. J. M., \& Kuiate, J. R. (2008). Antimicrobial activity of the crude extracts and compounds from Ficus chlamydocarpa and Ficus cordata (Moraceae). Journal of Ethnopharmacology, 120(1), 17-24. doi: 10.1016/j.jep.2008.07.026
Martínez, O., Salmerón, J., Epelde, L., Vicente, M. S., \& Vega, C. (2018). Quality enhancement of smoked sea bass (Dicentrarchus labrax) fillets by adding resveratrol and coating with chitosan and alginate edible films. Food Control, 85(1), 168-176. doi: 10.1016/j.foodcont.2017.10.003

Mittelstaedt, S., \& Carvalho, V. M. (2006). Escherichia coli enterohemorrágica (EHEC) 0157:H7. Revista do Instituto de Ciências da Saúde, 24(1), 175-182.

Mohamed, N. A., \& Al-Mehbad, N. Y. (2013). Novel terephthaloyl thiourea cross linked chitosan hydrogels as antibacterial and antifungal agents. International of Journal Biological Macromolecules, 57(1), 111-117. doi: 10.1016/j.ijbiomac.2013.03.007

National Committee for Clinical Laboratory Standards (2003). Performance standards for antimicrobial disk susceptibility tests. Approved standards - Eighth Edition. NCCLS document M02-A08. Wayne, Pennsylvania, USA. Retrieved from www.clsi.org

Ozogul, Y., Yuvka, I., Ucar, Y., Durmus, M., Kosker, A. R., Oz, M., \& Ozogul, F. (2017). Evaluation of effects of nanoemulsion based on herb essential oils (rosemary, laurel, thyme and sage) on sensory, chemical and microbiological quality of rainbow trout (Oncorhynchus mykiss) fillets during ice storage. LWT - Food Science Technology, 75(1), 677-684. doi: 10.1016/j.lwt.2016.10.009

R Core Team (2017). A language and environment for statistical computing. Vienna, Austria: R Foundation for Statistical Computing. Retrieved from http:// www.R-project.org

Sartoratto, A., Machado, A. L. M., Delarmelina, C., Figueira, G. M., Duarte, M. C. T., \& Reder, V. L. G. (2004). Composition and antimicrobial activity of essential oils from aromatic plants used in Brazil. Brazilian Journal of Microbiology, 35(4), 275-280. doi: 10.1590/S1517-83822004000300001

Seafood Brazil (2018). Seafood Brazil yearbook (4th.). Retrieved from http://seafoodbrasil.com.br/revista/ seafood-brasil-25

Silva, N., Junqueira, V. C. A., Silveira, N. F. A., Taniwaki, N. H., Santos, R. F. S., Gomes, R. A. R., \& Okazaki, M. M. (2010). Manual de métodos de análise microbiológica de alimentos e água (4a ed.). São Paulo: Varela.

Silveira, S. M., Cunha, A., Scheuermann, G. N., Secchi, F. L., Verruck, S., Krohn, M., \& Vieira, C. R. W. (2012). Composição química e atividade antibacteriana dos óleos essenciais. Revista do Instituto Adolfo Lutz, 71(3), 471-480. 
Sivakumar, D., \& Bautista-Baños, S. (2014). A review on the use of essential oils for postharvest decay control and maintenance of fruit quality during storage. Crop Protection, 64(1), 27-37. doi: 10.1016/j. cropro.2014.05.012

Upadhyay, A., Upadhyaya, I., Karumathil, D. P., Yin, H., Nair, M. S., Bhattaram, V.,... Venkitanarayanan, K. (2015). Control of Listeria monocytogenes on skinless frankfurters by coating with phytochemicals. LWT - Food Science Technology, 63(1), 37-42. doi: 10.1016/j.lwt.2015.03.100

United State Food and Drug Administration (2013). GRAS notice inventory. Retrieved from http://www. fda. gov

Vieira, B. B., Mafra, J. F., Bispo, A. S. R., Ferreira, M. A., Silva, F. L., Rodrigues, A. V. N., \& EvangelistaBarreto, N. S. (2019). Combination of chitosan coating and clove essential oil reduces lipid oxidation and microbial growth in frozen stored tambaqui (Colossoma macropomum) fillets. $L W T$ Food Science and Technology, 116(1), 108546. doi: 10.1016/j.lwt.2019.108546
Wang, J., \& Wang, H. (2011). Preparation of soluble p-aminobenzoyl chitosan ester by Schiff's base and antibacterial activity of the derivatives. International of Journal Biological Macromolecules, 48(3), 523529. doi: 10.1016/j.ijbiomac.2011.01.016

Yu, D., Li, P., Xu, Y., Jiang, Q., \& Xia, W. (2017). Physicochemical, microbiological, and sensory attributes of chitosan-coated grass carp (Ctenopharyngodon idellus) fillets stored at $4{ }^{\circ} \mathrm{C}$. International Journal of Food Properties, 20(2), 390-401. doi: 10.1080/10942912.2016.1163267

Yu, D., Xu, Y., Regenstein, J. M., Xia, W., Yang, F., Jiang, Q., \& Wang, B. (2018). The effects of edible chitosan-based coatings on flavor quality of raw grass carp (Ctenopharyngodon idellus) fillets during refrigerated storage. Food Chemistry, 242(1), 412420. doi: 10.1016/j.foodchem.2017.09.037 